\title{
Neo-liberalism, Partisanship, and Public Policies
}

\author{
Filippo Belloc • Antonio Nicita
}

Published online: 3 August 2012

(C) Springer Science+Business Media, LLC 2012

A wide-scholarly and interdisciplinary literature has analyzed neo-liberalism in various facets. Typically, this term is referred to as a new form of "political-economic governance premised on the extension of market relationships" (Larner, 2000:5). On the public policy side, it has been also depicted as Thatcherism or Reaganomics, and it has been identified with a political manifesto in which privatization and liberalization were the essence of public policies, especially for those economic services - namely those delivered in network industries - previously managed by state-owned monopolies.

While this first wave of neo-liberalism clearly identifies an ideological divide, as these policies were almost exclusively promoted by right-wing, conservative governments, its later diffusion around the world, progressively lost this original ideological bias.

Some authors have recently identified the policy agenda launched by President Clinton's 'market globalism' and Prime Minister Tony Blair's 'third way' (Roy et al. 2006) as "second-wave neo-liberalism". As the first wave, this new form of neo-liberalism encourages public policies aimed at promoting decentralization, market competition and private ownership in economic sectors previously reserved to monopoly. This second wave neo-liberalism is generally deemed to have started in the 1990s and to have pursued the principle of "strengthening social solidarity without dropping the neo-liberal ideal of market-oriented entrepreneurship" (Steger and Roy 2010).

There are indeed many examples of center-left executives embracing a political agenda based on the promotion of

\section{F. Belloc $(\bowtie)$}

Department of Economic Studies, University of Chieti-Pescara, Viale Pindaro 42,

65127, Pescara, Italy

e-mail: f.belloc@unich.it

\section{A. Nicita}

Department of Economics and Statistics, University of Siena,

Siena, Italy

e-mail: nicita@unisi.it market-oriented policies. This was the case, among others, of the Dutch Prime Minister Wim Kok, Italian Prime Ministers Romano Prodi and Massimo D'Alema, French Prime Ministers Pierre Beregovoy and Lionel Jospin, and the German Chancellor Gerard Schröder.

One question that still remains open in the political economy research agenda is whether the global diffusion of the neo-liberal policies constitutes a definitive trespassing of traditional ideological cleavages, thus the decline of ideological division itself (Manza 2010). Surprisingly, the empirical literature on the political economy of public policies contrasts with the view that the political determinants ceased to affect the adoption of market-oriented policies in the last 30 years (Alesina 1988; Alesina and Rosenthal 1995; Persson and Tabellini 2000). A large consensus could be found in this economic literature on the idea that right-wing parties should in principle promote market-oriented outcomes (such as privatization and liberalization), as this is embedded in their traditional ideological cleavages. Consequently, right-wing governments are deemed to promote market-oriented policies more intensively than left-wing executives around the world. This prediction has been unanimously confirmed by a scholarly-wide empirical literature on deregulation in network industries, which has focused on privatization policies, (i.e. on policies aimed at reducing or eliminating public ownership). Recent empirical works include Bortolotti and Pinotti (2008) and Belloc and Nicita (2012).

However, much less consensus is to be found in the literature with reference to liberalization policy (i.e. to policies aimed at reducing barriers to entry in network industries, independently of the nature of incumbent's ownership). While some authors (Pitlik 2007; Potrafke 2010) argue that, as for privatization, the likelihood of liberalization increases under right-wing governments, in recent research based on the most updated release of OECD data (Belloc and Nicita 2011a) we find the opposite results: the analysis of liberalization policies in 30 OECD network industries (including telecommunication, electricity, gas, railways), from 1975 to 2007, reveals a neglected role of so-called neo-liberalism in promoting left- 
wing market-oriented policy. However, in our empirical analysis this was only half of the story. Two results we found in our recent empirical analysis worked against the idea of a progressive bipartisan convergence towards deregulation: while on the one side, it is true that right-wing and left-wing parties adopted market-oriented policies, left-wing executives were able to liberalize to a greater extent than right-wing governments. This is a puzzle as it shows that the secondwave neo-liberalism has some distinguishing features we still need to investigate and to understand better.

\section{Understanding Left-Wing Liberalizations}

In last thirty years, in some countries, like Austria, Canada, France, Italy, Mexico and Sweden among others, left-wing governments have significantly introduced liberalization in network industries. Left-wing liberalization of network industries has been indeed remarkable during the 1990's and became even stronger in the last decade. For instance, in France, Law No. 108 concerning the access of new entrants to both electricity distribution and transmission networks was enacted in 2000 by the National Assembly under the Socialists, and in the same year the Socialists approved an unbundling decree that mandated France Telecom to provide both raw copper unbundling and shared access to its loops. Similarly, in Germany, the left-wing SPD approved in 2003 a new Telecommunications Act reducing a substantive part of entry barriers in the telecommunications market. Some new EU members such as the Czech Republic, Hungary, and Poland have also experienced analogous leftdriven initiatives Fig. 1 reports a descriptive analysis.

Figure 1 may suggest that traditional ideological cleavages might have vanished over time, at least for the liberalization of network industries. However, since left-wing executives were able to liberalize to a greater extent than right-wing governments, something rather different than a process of political convergence occurred. Indeed, Fig. 1 shows that while left-wing executives increasingly adopt liberalization policies, right-wing executive seem to fall behind. Thus, disentangling deregulation policies - namely privatization and liberalization in non-manufacturing sectors - turns out to be relevant in identifying how the left-wing political agenda has been affected by second-wave neoliberalism, in a way which nonetheless still reveals some persistent ideological divide.

So far, the empirical literature on the political economy of deregulation policies, has simply neglected the above puzzles, arguing that the right-wing significant adoption of privatization policies 'shall' be coupled with other marketoriented policies, such as liberalization.

While in our previous research (Belloc and Nicita 2011a), we have simply reported empirical findings, here we attempt to go one step further in discussing the above puzzles, by outlining six main alternative hypotheses for the observed ideological divide in the adoption of liberalization policies. In particular we discuss the following explanations for the observed left-wing liberalizations: liberalization as the result of ideological cleavages' trespass and/or policy diffusion; liberalization as a signal towards swing voters; liberalization as a 'policy reversal'; liberalization as a 'new' left-wing policy; liberalization as complement/substitute for other market-oriented policies; and liberalization as a weak, institutionally determined, market-oriented policy.

\section{The Trespass of Ideological Cleavages and the Role of Policy Diffusion}

This interpretation of left-wing activism in the liberalization of network industries is summarized in the following question: Are left-wing policy-makers trespassing ideological

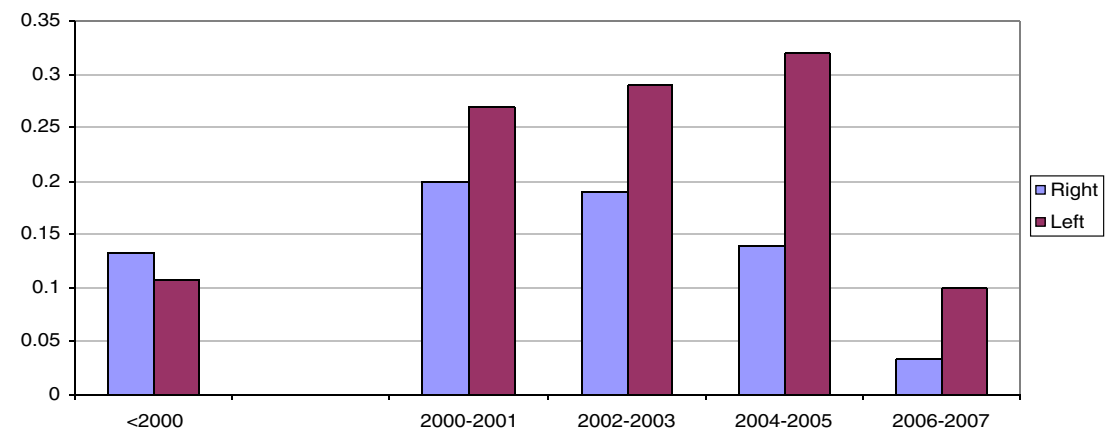

Fig. 1 Average liberalization intensity in seven network industries for 30 OECD countries and right-wing/left-wing governments (data: elaboration from OECD (2009) and World Bank (2008)). Belloc and Nicita (2011a). Liberalization is measured by subtracting the OECD's (2009) indicator of entry barriers from its maximum value (the index ranges from 0 to 6): the liberalization initiatives' intensity ( $\mathrm{Y}$ axis) is then calculated as two-year variations of the liberalization index. On the right side of the graph the average intensity before 2000 is displayed, on the left side two-year variations after 2000 are shown. The seven network industries considered are passenger air transport, telecommunications, electricity, gas, post, rail and road 
cleavages by shifting "to the right" their political platform for the governance of network industries?

This argument derives from the idea that economic liberalization may have created a progressive outcome during the last decades over 'class voting' (Clark and Lipset 2001; Nieuwbeerta and De Graaf 1999), as social class schemes are deemed to have been modified in post-industrial society (Butler and Savage 1995; Esping-Andersen 1993; Hout et al. 1995; Kriesi 1989; Manza and Brooks 1999). In this respect, the race towards liberalization policy (Pitlik 2007) which has characterized OECD countries in the last three decades may have changed the structure of political competition in such a way to become a post-ideological 'must have' receipt in political parties' policy toolkit, independently of their respective traditional cleavages. Thus, according to this view, liberalization policies should be deemed as neither rightist nor leftist, but simply as a common mandatory feature of modern globalized economies.

Policy diffusion and international 'clustering' may induce or even reinforce the above effect, 'forcing' bipartisan liberalization. It is well known that, whatever the political orientation of the party in office is, a given policy adoption in a group of countries might push for the same policy in other 'neighboring' countries. As argued by Dobbin et al. (2007), a transnational policy contagion might run through several concurring channels, as 'social construction' (the diffusion of new shared ideas), 'coercion' (the role of institutional determinants), 'competition' (the imitation of neighbors' policy to deter otherwise competitive disadvantages) and 'learning' (delayed policy adoption once neighbors' policy outcomes are revealed). The argument that supranational determinants might accelerate liberalization, independently of their political color, is confirmed by the role played on network industries liberalization by European Union membership and by a country's adhesion to Euro currency (Belloc and Nicita 2011a).

However, if policy diffusion is the answer, we should have found accordingly not only bipartisan liberalization, but also a similar intensity of liberalization adoption, both for left-wing and right-wing parties. Thus policy diffusion alone could not offer a convincing explanation of the reason why left-wing governments turned out to be even more active than right-wing ones in promoting liberalization.

\section{Liberalization as a Signal towards Swing Voters}

Another possible interpretation for our results may rely on the argument that the observed asymmetric liberalization patterns between left-wing and right-wing parties unveil a signaling strategy adopted by left-wing parties to attract otherwise right-leaning middle class voters (Downs 1957). Thus, with respect to the previous one, this interpretation does not rely on convergent bipartisan liberalization, but rather on a specific left-wing strategy. This interpretation mirrors the one provided by Biais and Perotti (2002) for right-wing's privatization rationale, based on a strategic signaling to win consensus over (left-wing) median voters. The argument goes as follows: by restructuring the economy and minimizing rent-seeking - through market discipline in liberalized sectors dominated by state-owned incumbents left-wing parties may attempt to attract median voters otherwise tempted to vote for the right party.

This conclusion however holds under specific political and electoral conditions. To gain median voters consensus through liberalization, a left-wing party may lose some of its own constituents who may abstain from voting or even choose another left-wing competitor. When the latter effect dominates, 'self-interested' left-wing parties will be induced not to compete for median voters. Consequently, in a political arena where median voters make the difference, a leftwing party should maintain all its traditional constituents when liberalizing, or at least confirming a portion of them sufficient to win the elections.

However a trade-off occurs, as, on the one side, strict legislation on employment protection may reduce, as a barrier to entry, new entrants' incentives to challenge incumbents' market power, thus weakening the credibility and even the expected impact of liberalization; while, on the other hand, credible liberalizations may generate shortterm adjustments and unemployment in a country's workforce, as a consequence of the restructuring of former legal monopolies, with offsetting effects on some left-wing constituents' side. A left-wing party's ability to credibly liberalize in order to gain the political consensus of otherwise right-leaning middle class voters, may thus strictly depend on its ability to extend its traditional platform 'to the right', while constrained by its constituents' preferences.

In this respect, some authors argue that one way to measure the 'distance' between partisan constituents and median class voters, is the level of income inequality (Biais and Perotti 2002). Unequal societies 'squeeze' the size, and thus the marginal value, of median voters for political competition. Should this assumption turn out to be correct, we should, other things being equal, expect more left-wing liberalization in countries with less income inequality.

In Fig. 2, we compare our OECD data on left-wing liberalizations (reported in Fig. 1) with World Bank data on inequality in 2000. The figure shows that the degree of left-wing liberalizations is negatively correlated with income inequality. This evidence may suggest that causality is more likely running from inequality to liberalizations of network industries, suggesting that left-wing parties tend to liberalize more in less unequal societies, rather than vice versa.

The significant left-wing liberalization wave registered from the 1990s onward, could be thus explained as an 


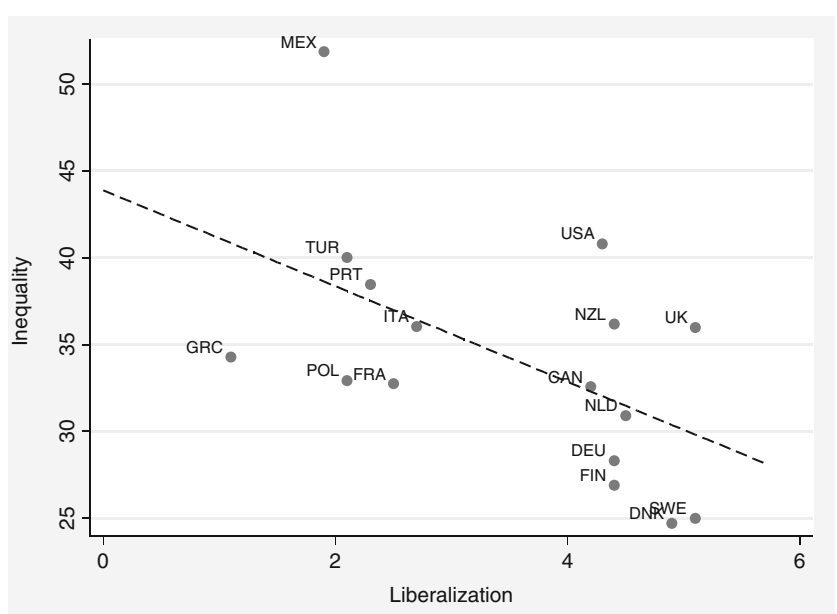

Fig. 2 Data on income inequality (Gini index) are obtained by World Bank (2009). Both liberalization and Gini values refer to 2000. Relative to Fig. 1, only OECD countries having a left-wing government in 2000 are included

attempt to find a strategic 'third way' positioning (Giddens 1998), after the fall of Communism. Italy, in this respect, is an important benchmark: the 1990s have been largely characterized by left-wing governments, with the participation of former communist parties, who significantly launched liberalization and privatization programs and appointed Antitrust and Regulatory Authorities. However, our analysis and data set can neither support nor exclude this interpretation, which needs, in order to be verified on specific grounds, to measure the evolution and distribution of voters' preferences in each country.

\section{Liberalization as Policy Reversal}

Another rationale for left-wing policy-makers implementing a market-oriented swing, as liberalization, has been identified, among others, by Rodrik (1993) and Cukierman and Tommasi (1998), and goes under the label of "policy reversals". They argue that, under given circumstances, a policy switch between right-wing and left-wing parties, with respect to their traditional platforms turns out to be optimal. Have leftist parties moved to the right in their rhetoric and policies (Potrafke 2010; Ross 2000)?

The intuition behind this is that governments have private information on the current state of a political issue and make their decision in order to maximize the interest of the majority of voters. Given this information asymmetry, in order to gain consensus from the largest part of voters, governments have to transmit to the public their private information about the relative desirability of a given policy.

However, the success of policy announcement will depend on a political party's ability to be credible when transmitting information and motivation to the public. A political party will turn out to be more credible the greater is the distance of the policy announced from its political 'ideal point'. Thus moderate right-wing policies are more likely to be implemented by right-wing parties (and similarly for the left), but extreme right-wing policies are more likely to be implemented by left-wing parties (and vice versa). The argument is that, though a policy reversal, "the public has less reason to suspect that the right-wing policy is proposed solely because of the natural ideological tendencies of the party in office, i.e., it may be perceived as an objectively motivated policy" (Cukierman and Tommasi 1998).

We should then ask whether left-wing liberalization of network industries falls into the category of 'policy reversals', thus explaining the observed switch, over time, between the left and the right on the implementation of liberalization policy. Put another way: Are left-wing parties more credible than right-wing ones in announcing liberalization of network industries?

On the one side, the answer is negative. Liberalization is generally perceived to be closer to right-wing 'ideal points' rather than to left-wing ones. After all it is a moderate rather than an 'extreme' right-wing policy, as for instance privatization is. Thus we should exclude left-wing liberalization being the outcome of a policy reversal. On the other hand, another reason not to reject the hypothesis of left-wing policy reversal is that one of the main conditions for having that policy is that the policy switch that is desirable (for the majority of voters) "should be considerable and relatively rare". We should thus expect dramatic shocks, concentrated in time, rather than the gradualism and the continuity we observed of left-wing liberalization policy.

\section{Liberalization as a 'New' Left-Wing Policy}

The three alternative arguments already outlined derive from the idea that liberalizations are a kind of pro-market policy mirroring a right-wing cleavage. Accordingly, the alternative rationales for liberalization, suggested above, imply left-wing partys' policy decisions 'against' their traditional ideological cleavages.

Here we focus on an opposite rationale: the observed liberalization wave could be well motivated as a 'new' left-wing policy tool aimed at maximizing the interests of left-wing party's own constituents against right-wing cleavages.

This argument has been pointed out by Alesina and Giavazzi (2007), under the slogan "Economic liberalism is left-wing". The argument goes on saying that the "Left should learn to love liberalism", since market-oriented policies imply shifting financing from taxpayers to the users themselves and, as such, they tend to eliminate rents and to 
increase productivity. As a consequence, "goals that are traditionally held dear by the European left - like protection of the economically weakest and aversion to excessive inequality and un-earned rewards to insiders - should lead the left to adopt pro-market policies".

Alesina and Giavazzi (2007) share the idea that liberalization policies (not only the ones limited to network industries) reduce inequality, thus implicitly admitting that leftwing government should implement these policies especially when a high level of income inequality is observed. Leftwing governments may use liberalization of network industries as a way indirectly to redistribute rents towards lowincome customers, and to grant universal access obligations and a minimal level of quality (Kwoka 2005; Armstrong and Sappington 2006). However, it could be the case that a leftwing party would be unlikely to launch strong liberalization programs under high income inequality levels - unless it succeeded in 'advertising' these as 'policy reversals' (Rodrik 2003; Cukierman and Tommasi 1998). Precisely because their own constituents might be reluctant to sustain policies which might be welfare improving in the long term, but that are perceived as being certainly detrimental in the short term, left-wing parties may abstain from liberalization as income inequality grows.

A paradoxical trade-off then might emerge between the economic impact of liberalization in reducing inequality and a left-wing party's decision to liberalize. The paradox here is that the likelihood of left-wing liberalization policies will be higher precisely when they are needed less, since, following Alesina and Giavazzi (2007), their redistributive impact will be less relevant for the society.

\section{Liberalization as a Complement/Substitute for Other Market-Oriented Policies}

Another interpretation for left-wing liberalization policies in network industries derives from liberalization being perceived by leftist policy makers as a complement or as a substitute for other market oriented policy. As to complementarities, liberalization might be introduced by left-wing governments as a pre-requisite for future market-oriented policy, including privatization, under the belief that while competition may well lead to privatization, the opposite is not true (Stiglitz 1999). Thus, left-wing parties may promote liberalization as a complementary policy to previous or future privatization (Belloc and Nicita 2011b). In Newbery's (1997) words, "competition is difficult to achieve within the public sector, so there is a natural complement between liberalization and privatization." According to Newbery (1997), "privatization is necessary but not sufficient" to obtain market-oriented outcomes.
In other words, if a distinctive feature of a marketoriented policy is that of generating market-oriented outcomes, privatization policy alone could not constitute an exhaustive proxy of a general political preference towards promoting such outcomes. Since privatization "is primarily about ownership rather than control, as utilities can face remarkably similar regulation under public or private ownership", the quality of regulation is crucial to test the impact of privatization on market outcomes. Liberalization, in contrast, "subjects utilities to market forces, and can induce more dramatic changes in performance than privatization alone" (Newbery 1997).

Particularly for network industries, the effectiveness of privatizations on economic performance seem to strictly depend on the degree of (joint) liberalization policy (Newbery 1997, 2002; Levi-Faur 2003; Armstrong and Sappington 2006; Guriev and Megginson 2007). The reason has been clarified - among others - by Nicoletti and Scarpetta (2003), who argued that in network industries "the effects of privatization are closely related to the creation of sufficient market pressures in the potentially competitive segments of the industry as well as to the regulation of access to the noncompetitive segments." Absent an effective well-designed regulatory framework, especially in industries with natural monopoly elements, "the impact of privatization on efficiency is still largely an empirical matter to be verified at the industry or firm level" (Nicoletti and Scarpetta 2003). Thus, at least for network industries, liberalization processes seem to play a crucial role in determining the extent of market competition and the success of privatization policies in granting procompetitive outcomes. Besides, Acemoglu et al. (2003) show that when there is a weak 'institutional capacity' for proper state-controlled regulation of privatized firms, a more direct state control should be encouraged and since (good) liberalization maintains public ownership, while introducing competition, it could represent a proper candidate market-oriented policy for weak institutional environments. The above arguments may help explain why left-wing parties may adopt liberalization as a way to enhance other (past or future) market oriented policy, but fail to provide a convincing explanation of the reason why right-wing parties should behave differently.

\section{Liberalization as a Weak, Institutionally Determined, Market-Oriented Policy}

Finally, another motivation for left-wing liberalization could be referred to the institutional political environment within which political parties decide their policies. This argument relies on the idea that the presence in office of left-wing parties in a heterogeneous coalition and/or under proportional electoral systems, might induce liberalization either as a way to deter stronger market oriented policy, for instance 
through the exercise of veto powers against decision to privatize (Bortolotti and Pinotti 2008), or as a way of conceding 'some' market oriented policy to other political members' in the coalition, in exchange of redistributive policies towards left-wing constituents. Thus in some weak political-institutional settings, when left-wing party is in office, liberalization could be adopted as the weakest market oriented policy the left-wing party is willing to concede to other members of the coalition. A symmetric explanation might hold when right-wing parties are in office and coalitional veto powers force towards the weakest form of market-oriented policy.

In Fig. 3, we compare OECD data on liberalization (OECD 2009) and World bank Data on Government Heterogeneity. Liberalization is measured by subtracting the OECD's (2009) indicator of entry barriers from its maximum value (the index ranges from 0 to 6). Government's heterogeneity is defined by the World Bank as the probability that two deputies picked at random from among the government parties will be of different parties (source: World Bank 2008). Figure 3 shows that there is slight but significant correlation between Government's heterogeneity and the average liberalization level for the 30 OECD countries considered in Fig. 1, and confirms a positive and statistically significant effect on entry liberalization.

\section{Filling the Research Agenda}

It is worth emphasizing that any attempt to single out from the above any dominant interpretation for the

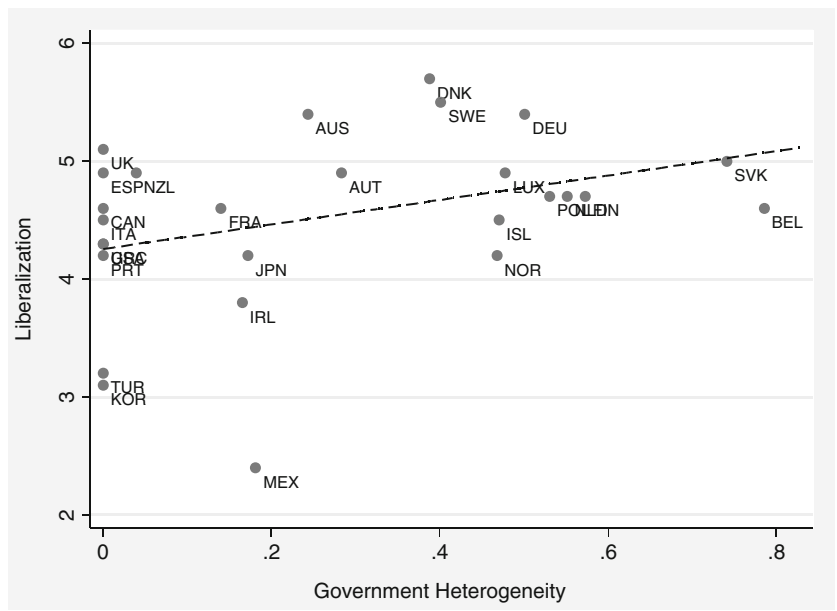

Fig. 3 Economic liberalization and government heterogeneity. Data are the most updated available and refer to 2006; liberalization is measured by subtracting the OECD's (2009) indicator of entry barriers from its maximum value (the index ranges from 0 to 6 ), government heterogeneity is defined as the probability that two deputies picked at random from among the government parties will be of different parties (World Bank 2008) observed left-wing liberalization wave is destined to fail. The above might be concurring explanations that need further research.

The research puzzle to be addressed by future research is the following: why do left-wing parties in office liberalize, and why do they seem to liberalize, on average, to a greater extent than right-wing governments do?

We argue that existing theoretical arguments regarding political determinants of market-oriented policies do not provide unambiguous criteria to support the existence of a clear Left-Right divide on liberalization mirroring the one theorized and observed for privatization.

Our purpose here was simply to outline how the economic literature on the political determinants of market-oriented policies failed in two respects so far: (i) in acknowledging the relevance of left-wing executive liberalization in OECD network industries, over the last 30 years and (ii) in explaining why right-wing governments resulted to be less active than left-wing ones in promoting liberalization. The convergence process between Left and Right is at least truncated, as when left-wing governments started 'imitating' rightwing executives' liberalizations, the latter 'reduced' their liberalization intensity.

Partisanship and political institutions still matter for liberalization. But the analysis of the political rationale and the institutional determinants behind deregulation of network industries is still in its infancy and further research is needed to properly address the results and the stylized facts we outline. To conclude, a comprehensive theoretical framework is still needed in order to understand the economic and political rationale, respectively, for right-wing and leftwing parties to hinder or promote liberalization policy in network industries.

\section{Further Reading}

Acemoglu, D., Johnson, S., Robinson, J., \& Thaicharoen, Y. 2003. Institutional Causes, Macroeconomic Symptoms: Volatility, Crises and Growth. Journal of Monetary Economics, 50(1), 49-123.

Alesina, A. 1988. Macroeconomics and Politics. In S. Fisher (Ed.), NBER Macroeconomics Annual (pp. 17-52). Cambridge (MA): MIT Press.

Alesina, A., \& Giavazzi, F. 2007. Il Liberismo è di Sinistra. Milano: Il Saggiatore.

Alesina, A., \& Rosenthal, H. 1995. Partisan Politics, Divided Government, and the Economy. Cambridge: Cambridge University Press.

Armstrong, M., \& Sappington, D. 2006. Regulation, Competition and Liberalization. Journal of Economic Literature, 32(2), 353-380.

Belloc, F., \& Nicita, A. 2011a. The Political Determinants of Liberalization: Do Ideological Cleavages Still Matter? International Review of Economics, 58(2), 121-145.

Belloc, F., and Nicita, A. 2011b. Liberalization-Privatization Paths: Policies and Politics. Working Paper N. 609, March 2011, Dept. of Economics and Statistics University of Siena 
Belloc, F., \& Nicita, A. 2012. Partisan Privatizations: Assessing the Ideological Bias. Applied Economics Letters, 19(10), 959-963.

Biais, B., \& Perotti, E. 2002. Machiavellian Privatization. American Economic Review, 92(1), 240-258.

Bortolotti, B., \& Pinotti, P. 2008. Delayed Privatization. Public Choice, 136(3), 331-351.

Butler, T. And, \& Savage, M. 1995. Social Change and the Middle Class. London: UCL Press.

Clark, T. N., \& Lipset, S. M. (Eds.). 2001. The Breakdown of Class Politics: A Debate on Post-Industrial Stratification. Washington: Woodrow Wilson Center Press.

Conway, P., and Nicoletti, G. 2006. Product Market Regulation in the Non-Manufacturing Sectors of OECD Countries: Measurement and Highlights. OECD Economics Department Working Papers No. 530.

Cukierman, A., \& Tommasi, M. 1998. When Does It Take a Nixon to Go to China? American Economic Review, 88(1), 180-197.

Dobbin, F., Simmons, B., \& Garrett, G. 2007. The Global Diffusion of Public Policies: Social Construction, Coercion, Competition, or Learning? Annual Review of Sociology, 33, 449-472.

Downs, A. 1957. An Economic theory of Democracy. New York: Harper and Row.

Esping-Andersen, G. (Ed.). 1993. Changing Classes: Stratification and Mobility in Post-Industrial Societies. London: Sage.

Giddens, A. 1998. The Third Way. The Renewal of Social Democracy: Polity Press.

Guriev, S., \& Megginson, W. 2007. Privatization: What Have We Learned? In F. Bourguignon \& B. Pleskovic (Eds.), Beyond Transition, Proceedings of the 18th ABCDE. Washington D.C: World Bank.

Hout, M., Brooks, C., \& Manza, J. 1995. The Democratic Class Struggle in the United States. American Sociological Review, 60, 805-828.

Kriesi, H. 1989. New Social Movements and the New Class in the Netherlands. The American Journal of Sociology, 94(5), 10781116.

Kwoka, J. 2005. Electric Power Distribution: Economies of Scale, Mergers and Restructuring. Applied Economics, 20, 2373-2386.

Larner, W. 2000. Neo-Liberalism: Policy, Ideology, Governmentality. Studies in Political Economy, 63, 5-25.

Levi-Faur, D. 2003. The Politics of Liberalization. Nuffield College Working Paper in Politics 2002-W13, Oxford.

Manza, J., and Brooks, C. 1999. Social Cleavages and Political Change: Voter Alignments and U.S. Party Coalitions. Oxford University Press, Oxford.

Manza, J. 2010. Liberalism's Inevitability? in Society, 47: 477-483
Newbery, D. M. 1997. Privatization and Liberalization of Network Utilities. European Economic Review, 41(3-5), 357-383.

Newbery, D. M. 2002. Problems of Liberalizing the Electricity Industry. European Economic Review, 46(4-5), 919-927.

Nieuwbeerta, P. And, \& De Graaf, N. D. 1999. Traditional Class Voting in Twenty Postwar Societies. In G. Evans (Ed.), The End of Class Politics? Class Voting in Comparative Perspective (pp. 23-58). Oxford: Oxford University Press.

Nicoletti, G., and Scarpetta, S. 2003. Regulation, Productivity, and Growth: OECD Evidence. World Bank, Policy Research Working Paper No. 2944.

OECD. 2009. ETCR Indicators, available at http://www.oecd.org (February 2010).

Persson, T., \& Tabellini, G. 2000. Political Economics: Explaining Economic Policy. Cambridge (MA): MIT Press.

Pitlik, H. 2007. A Race to Liberalization? Diffusion of Economic Policy Reform among OECD Economies. Public Choice, 132, 159-178.

Potrafke, N. 2010. Does Government Ideology Influence Deregulation of Product Markets? Empirical Evidence from OECD Countries. Public Choice, forthcoming.

Rodrik, D. 1993. The Positive Economics of Policy Reform. American Economic Review, 83, 356-361.

Rodrik, D. 2003. 'Growth Strategies', Technical Report Working Paper 10050. Cambridge (MA): NBER.

Ross, F. 2000. Beyond Left and Right: The New Partisan Politics of Welfare. Governance: An International Journal of Policy and Administration, 13(2), 155-183.

Roy, R. K., Denzau, A. T., \& Willett, T. D. (Eds.). 2006. Neoliberalism: National and Regional Experiments with Global Ideas. New York: Routledge.

Steger, M. B., \& Roy, R. K. 2010. Neoliberalism: A Very Short Introduction. New York: Oxford University Press.

Stiglitz, J. 1999. 'Promoting Competition in Telecommunications', Paper $\mathrm{N}^{\circ}$ 2, Centro de Estudios Economicos de la Regulacion Instituto de Economia, Universidad Argentina de la Empresa.

World Bank. 2008. Database of Political Institutions, available at http://econ.worldbank.org (February 2010).

World Bank. 2009. World Development Indicators, Washington.

Filippo Belloc is assistant professor of public economics at the University of Chieti-Pescara.

Antonio Nicita is associate professor of economic policy at the University of Siena. 